\title{
Figurative Transformation of Free Compound Words into Adjectival Phraseological Units in the Albanian and English Language to be Acquired from the Students
}

\author{
Dr. Lediana Beshaj \\ Universiteti "Hëna e plotë" Beder \\ Departamenti i gjuhës angleze \\ E-mail: beshajlediana@hotmail.com
}

\begin{abstract}
One of the crucial features of phraseology is figurative meanings the words get. In this paper it is aimed to see the figurative transformation of similies and metaphors considered as free compound words into adjectival phraseological units in the Albanian and English language. The examples are extracted from the "Phraseological Dictionary of the Albanian language" compiled by J. Thomai, from the English-Albanian Phraseological Dictionary of I. Stefanllari, as well as from the lexical file departament of the Albanian language. A special focus is given to the meaning that these phraseological units have and how can they be acquired by the students, in order to have a native like fluency of the foreign language. Phraseological units are very hard to be acquired by the students as their meaning is different (not all the time though) from the words that this phraseological unit is compounded of. In the English language the adjective is one of the most important part of speech that describes, identifies, modifies, or quantifies something (a noun or a pronoun). Thus, adjective are used frequently in all types of discourses and styles. The area where the adjectival phraseological units are commonly used is literature and that is where the figurative meaning is definitely appreciated and emphasied to make it more attractive to the reader and to make one's writings colorful. Hopefully, these adjectival phraseological units will help and will be used by anyone who wishes to write aristically.
\end{abstract}

Keywords: phraseology, simile, metaphor, adjectival phraseological units

\section{Introduction}

Figurative language makes use of specific words, but it is emphasised that "it is embodied more in phraseological units" ( Memisha V. 2002) than in words, as these phraseological units are laden with figurative meaning. Though, for a learner of a foreign language it is quite difficult to understand the meaning of the phraseological units as their meaning is quite hard to grasp. On the other hand it is stated that learning phraseological units makes the learner more confident due to the vocabulary background enhancement. To have and to use an extensive vocabulary background is really important because it shows proficiency. Phraseological units are closely related to a country's culture, history and traditions. Thus making use of phraseological units enriches one's vocabulary as well as the awareness towards the customs, traditions, culture, history, psychology of the people of the target country. For example, the phraseological unit 'Jack of all trade, but master of none" means that a person that is competent with many skills, but is not necessarily outstanding in any particular one. To know the meaning and to use this phraseological unit it means that the person who uses it, knows that it is related to the Elizabethan English. At that time people who knew Latin and English were considered well educated and they employed such phrases. One of them was Johannes factotum ("Johnny do-it-all") which was used with the same negative connotation that "Jack of all trades, but master of none" has today.

Nevertheless, another factor is that by knowing phraseological units, makes one feel more self confident in the interaction with foreigners. Phraseological units are part of the colloquial language, as well and as such it is appropriate for the learner of that language to acquire them and use them accurately. Let's consider the phraseological unit "Let's go Dutch" if someone does not know the meaning of this, he/she would say that it means 'let's go to the Netherland', whereas in fact it means ' each person pays for himself/herself.

Another issue related to phraseological units acquisition is related to the different contexts belonging to various disciplines like pragmalinguistics, sociopragmatics etc. 
Danesi (1992) observed how the metaphorical structures of the target language shape the codified concepts and how the conceptual codification reflects the metaphorical structure of the target language (conceptual fluency) have an impact on the language acquisition. He investigates that deficiency in the metaphorical competence, which is closely related to the culture, presents a great obstacle for the foreign language learners to be fluent to the level of the native speakers. Lazar (1996) emphasies that in the strategies which are used to expand knowledges and to produce figurative language as well as to understand it, includes a 'deduction' process, inference.

Students must be encouraged to discover the figurative meanings, at the same time pedagogical instructions must aim to go beyond the conventional forms, to be more original, efficient and idiosyncretic. Students must be sensitized to know the cultural importance due to the fact that the figurative meanings are assessed from the cultural point of view.

Glucksberg ( 1996) emphasises the importance of the specific cultural knowledge which is part of the figurative language competence, where the figurative meanings are deeply rooted in culture. Cultural and social values are perceptions and interpretations of the discourse, which are indirectly dominant. For Glucksberg, this kind of dependency on the cultural communicative competence is somehow a serious problem for the students, who are learning a foreign language. A student who learns a foreign language, does not only know two languages, but also must know two cultures. By knowing two cultures they would also be able to acquire the figurative language as well.

Littlemore (2003) comments on the influence of the cultural background and the impact it has when one wants to interpret a metaphor. Furthermore, by observing the competence concept and the its relation with the foreing language learning process, she emphasises the complexity of this competence. She thinks that the cultural competence depends a lot on the cognitive abilities of the individual ( the less advanced is a student in learning a foreign language the poorer is his figurative competence). The context plays a pivotal role in the process of understanding and producing figurative language and especially using figurative devices. Making use of different contexts in different fields enables the students to improve not only the linguistic competence, but at the same time the competence in using the figurative language.

The reason why it is difficult to understand the figurative meaning is because it is dfficult to memorize phraseological units and use them appropriately. However, this is even more difficult when the language to be learned is English, as it is an idiomatic language.

The main focus of this paper is to observe this phraseological units, the way they are formed, as well as which are the means used to form them, especially the adjectival phraseological units. These adjectival phraseological units are very useful to be learned because the adjective is one of the main parts of speech in a sentence and replacing the adjective ith an idiom or phraseological units makes the speech, or the writing more interesting and colorful. The majority of adjectival phraseological units are formed by the use of simile and metaphor, thus they deserve a special attention in the process of teaching and learning.

\section{Adjectival Phraseological units formed by simile}

According to the definition of Punter (2007), a simile is the simpliest form of metaphor where two objects are compared. A comparison in an explicit way compares the similarities, whereas the more advanced forms of metaphor aim to surprise the listener, the reader by omitting the comparative conjuctions (Knowles; Moon 2006: 8). Metaphors and conjuctions have in common the fact that both include ' conceptual (mental) activities (Mac Cormac 1985: 36). The creator of metaphor or simile must bear in mind a combination of referents, and the listener must search for a connection between the referents and must notice the changes between them. For example, if we say "someone is a fox" it is a metaphor, but if we say "he is like a fox" it is a simile.

Yet, it can be said that there is a little difference between the metaphor and the simile, apart from when they are used in phraseology, where the difference is important. As it is mentioned already, a metaphor is literally imposible or not true; without taking into consideration the behaviour of the person, a human being is always a human being and not a fox. On the contrary, a simile different from a metaphor is literally possible or real, no matter how inconvenient is the comparison. Ortony (1980: 189) arguments that the process of making comparison is of an essential importance in order to understand the comparison. The comparisons are more or less successful or convenient to the degree in which the things are being compared as similar. 
A simile is a literary device which is used in comprehensive linguistics, but on the other hand it is even one of the common way of figurative transforming the free word group into a phraseological unit.

Comparing by using simile performs different functions (Fromilhague 1995:88-94). First of all they help us communicate accurately and effectively. Secondly, they function as cognitive means which help us see the world in different ways as they establish an interrelation of simlarity with the world that sorrounds us. An ordinary comparison, which is estimating and not official, emerges in other types of phraseological units, in the bookish style in different kinds of genres, in order to create "the ilusion of the verbal means" (Moon 1998: 267-68). The selections of the units is closely related to the culture and in some cases it creates many lexical-cultural problems. The comparison in the English language becomes more evident by the use of comparative conjuctions like: like, as:

Like a bad penny - si paraja e kuqe.

I purposely didn't introduce you to my sister-in-law at the party, because once she gets an entry into anybody's home she keeps turning up like a bad penny.

$\sim$ Like a bat out of hell - si rrufe si plumb, vetëtimthi.

When someone shouted "Fire!", I got out of that house like a bat out of hell..

$\sim$ Like a bird - flutur, flutur e shpejtë.

My new car goes like a bird.

$\sim$ Like a bull in a china shop - i ngathët si buall.

I wish I could mark everything fragile, that's how I feel, trucked in here. Listening to her, I feel like a bull in a china shop.

$\sim$ Like a bullet out of/from a gun - si plumb, si vetëtimë, vetëtimthi.

Well, as soon as I read that bit in the 'Daily Tale' about the Loch Ness Monster being sent in Little Todday and Great Todday I was off like a bullet out of a gun. I mean to say, I don't want to miss seeing this monster.

Like a lamb - si qengj, i urtë si qengj.

He went up to his solicitor's office like a lamb, while Mrs.Pettigrew waited in the car below.

$\sim$ As black as coal - i zi si qymyri , i zi sterrë.

Look at your hands, boy, they're as black as coal - you can't come to the table like that.

$\sim$ As busy as a bee - si bletë punëtore.

The children are busy as bees, helping their mother in the garden.

My wife never has time to get bored. She is as busy as a bee from morning to night.

$\sim$ As clean as a new pin - i pastër dritë.

Jim's mother was a big woman, who kept her house as clean as a new pin.

$\sim$ As clear as crystal - i pastër, i qartë, i tejdukshëm si kristal.

The river ran as clear as crystal and if you watched closely you could now and then catch a glimpse of a trout hovering over the pebbles on the bottom.

$\sim$ As clear as day/daylight - si drita e diellit.

The matter was as clear as daylight and would be disposed of in half an hour or so.

$\sim$ As cunning as a fox - dinak si dhelpër.

There is a good deal of crooked dealing in the property business but the people involved in it are as cunning as foxes and know how to keep just on the right side of the law.

$\sim$ As cold as ice - akull i ftohtë. 
The central heating had been switched off and the room was as cold as ice.

$\sim$ As deep as well $-i$ thellë pus.

'I never knew Harold could handle a boat!' 'There's a lot we don't know about Harold. He's as deep as a well.

As easy/simple as ABC - fare kollaj, fare lehtë, si bukë e djathë.

You will quickly learn how to use this machine; it's as simple as $A B C$.

First lessons in any subject are usually designed to make you think that the whole course is going to be as easy as ABC.

$\sim$ As fit as a fiddle - si kokërr molle.

'How are you feeling, Tom?' 'Fit as a fiddle'

l'll tell your parents that you're as fit as a fiddle and having the time of your life.

$\sim$ As hard as steel - i fortë si çeliku.

General discipline and academic achievements improved greatly under the headmastership of Mr.Gray, a man as hard as steel, but very just.

$\sim$ As hard as a stone - $i$ fortë si shkëmb.

I can't do any digging today, the ground's as hard as stone after last night's frost.

$\sim$ As heavy as lead - i rëndë plumb.

When he woke the following morning his throat felt sore and swollen and his limbs heavy as lead.

As light as a feather - $\mathrm{i}$ lehtë pendë.

'Can you manage to carry her?' 'Oh, she's as light as a feather'.

As meek as a lamb - $i$ urtë, i butë si qengj.

If he'd thought I would sit there meek as lamb while he abused my family, he must have got a real surprise.

$\sim$ As obstinate/stubborn as a mule - kokëfortë si mushka.

But this is the old thing, though he is impulsive he's as obstinate as a mule.

$\sim$ As quick as lighting - si rrufe.

I didn't mean to let the dog out, but he shot past me, as quick as lighting, when I opened the door to the postman.

$\sim$ As quiet/silent/still as the grave/tomb - i heshtur si varri.

I do miss the children. The house seems as silent as the grave without them.

There's no use peering through the letter-box. The place is as still as the grave. They must have forgotten we were coming.

As sweet as honey - $i$ ëmbël mjaltë.

I can't drink this tea. It's as sweet as honey.

She's the kind of woman who'll be sweet as honey in your face and as malicious as hell behind your back.

$\sim$ As white as chalk/snowla sheet - e bardhë si bora, i bardhë qumësht

The sheets were rough but as white as snow.

It was dreadful to see him lying there white as a sheet and in such pain.

His face was white as chalk when he arrived home from work this evening. 
In the Albanian language there is a great number of phraseological units formed by the transformation of the free compound, which have one of their components a comaparative conjuction like : si, posi:

$\sim($ Është) si qen i rrahur (i dëbuar) (dikush) e ka pësuar një herë keq në jetë dhe nuk ka më guxim e nuk vetëvepron, ngaqë ruhet se mos e pëson përsëri; (është) ka me një bri; ka rënë nga dardha;

$\sim$ (Rri) si mace e lagur (dikush) mospërf. rri i turpëruar para të tjerëve për shkak se ka bërë diçka të keqe, rri kokulur e pa bërë zë; (rri) si pulë e lagur;

Shet mend (dikush) përpiqet të tregohet më i ditur a më i zoti sesa është; është mendjemadh e mburret përpara të tjerëve; si qeni në qerre;

$\sim($ Del) si kërriçi para gomarit (dikush) tall. nuk respekton radhën para të mëdhenjve, nuk është i përmbajtur, flet pa radhë; (del) si mëzi para pelës; (del) si boshti para furkës; gjëkundi;

S'i zë bytha vend (dikujt) keq. thjeshtligj. nuk ngulet në punë; është shumë i lëvizshëm, nuk shtrohet a nuk ulet

(Flet) si miza në qyp (dikush). 1. Flet me zë të ulët e mbyturazi, mezi dëgjohet e nuk merret vesh fare ç'thotë. 2. Nuk është i qartë në mendime, nuk e kupton çfarë kërkon;

(Janë) si bletë e plotë rrojnë së bashku, të pasur e të lumtur (për një familje etj.);

$\sim$ (Ka) si bletë e plotë ka me shumicë, është bollëk të mirash.

\section{Adjectival Phraseological units formed by metaphor}

Phraseological units formed by the use of metaphor are numerous. According to Lakoff and Johnson (1980), most of the metaphors have a conventional nature as they are used in every day speech, which means that they are stable phrases that are used by systematically by people. For these scholars the conventional metaphor are created from the culture of a certain country to determine a specific kind of reality. The impact that culture displays in metaphors is obvious and commonplace; it is present in different types of discourses as well as in different functional styles. For Lakoff and Johnson (1980), the meaning of the new metaphors depends and it is assessed partly from the culture and partly from the personal experiences of the user. The appropriate use of the metaphors is not an easy process or something to be copied as an unalterable phraseological unit used by a particular social group, but there is always an individual element for the metaphor's construction which derives from culture, because people are influenced by their personal experience as well from the exposure to different types of social discourses. Meanwhile according to V. Memisha (2008) "The creation of a phraseological units undergoes a process of four phases: free word group, simile, metaphor ( which implies the dropping of the comparative conjuctions), phraseological unit ( the creation of a new lexicalical unit with all the characteristics and functions that its equivalent has; the word)" (Memisha, 2001)

Memisha asserts that " taking into account the lexical materials that we have in our hands, it is observed that during these latest decades, we observe that Albanian language as well is experiencing an enormous metaphorisation phase, which is a tendency acquired by the languages, which have elaborated functional styles. The minimal structures, where this metaphorization occurs ( not metaphorisation in the narrow sense, but as as a inclusive semantic shift) build multiple relation between words which enrich their structures with new semantic valences." (Memisha, 2008)

In the Albanian language it is noticed that by making use of metaphors, multiple meanings emerge according to the similarities in shape, dimension, colors, roughness, be it concrete or abstract; thus, it can be emphasised that this is a way of enriching words with new meanings. In this point of view, the metaphor is displayed as one of the main devices for the formation of phraseological units as well as the most productive one in a certain language. The examples extracted from the phraseological dictionary demonstrate and support this view.

\section{Adjectival phraseological units formed by the metaphorisation process in English:}

Bad egg - njeri i poshtër, njeri i keq, maskara; njeri i pabesë 
Their nephew, who was a real bad egg, got his hands on nearly all the old couple's savings on the pretext that he would buy them a little place in the country.

I would never trust Brown: he is a bad egg.

$\sim$ Big cheese/shot/wheel/wig - njeri me peshë, njeri me zë, njeri me shumë rëndësi

Here comes the big cheese himself. Have got the red carpet yet?

Make sure you keep friendly with that chap: he's a big shot in the Civil Service.

$\sim$ Cold fish, a - njeri i ftohtë

I find Frank's company boring: he's a bit of a cold fish.

$\sim$ Dark horse, a - person (kandidat) pak i njohur njeri i pashfaqur

He's a bit of a dark horse: He was earning a fortune, but nobody knew. Whatever the outcome of the election, Mr. Michael Foot-the dark horse- emerges more and more as a figure of moderation.

\section{Adjectival phraseological units formed by the metaphorisation process in Albanian:}

Arushë mali (e malit) njeri i fuqishëm e i guximshëm; njeri që nuk lodhet kurrë. Kur i therrët ai Sokoli Halil: / "Ku më je, i thotë, arusha e malit, / Ndihmë do të vijnë agët e Jutbinës. (Folk.). Dalip Karaji, një arushë mali, / I ra asqerit mu te zalli. (Folk.).

(Let. art.).

$\sim$ Bagëti e trashë shar. njeri i paditur, i pagdhendur a budalla. - Fali Zot, bagëti e trashë, nuk dinë ç'bëjnë.

Bletë shkëmbi njeri i padobishëm, që nuk jep fryte në punë; kalli pa bukë. - Ma kanë sjellë një sekretar, po ai bletë shkëmbi, më mirë të mos e kesh. (Pub.).

Bollë e vrarë njeri fare i lodhur e i këputur; që s'ka fuqi fare e s'lëviz dot. - Ku më je, o bollë e vrarë, që s'po të shohim ka ditë? (Ligj. fol.).

Buf kënete shar. njeri i shëndoshë, i plogët e përtac, njeri i fjetur; njeri i trashë nga mendja. - Kush qe ai buf kënete që t'i tha këto gjëra? Dyshoj shumë në intelektin e tij. (Let. art.).

Me buzë të plasur shumë i dëshpëruar, i pikëlluar; me shpirt të plasur; me zemër të plasur. 0 moj Shqipëriz' e dashur, / Mëmëdhe, / Të shoh me buzë të plasur, / Si më sheh. (Let. art.).

Me buzë varur (të varur) i vrenjtur, i ngrysur, i zemëruar; i pakënaqur e i mërzitur; gjithë (tërë) buzë; (gjithë, tërë) hundë e buzë; me hundë varur (të varura). Përse sot me buzë varur ky Çurçilli, / Këtë ditë kur me gaz këndon bilbili? (Let. art.). Me buzë të varura i rrinte edhe plaka, që më parë e priste me peqe e lepe. (Let. art.).

Dash me flokë burrë i shquar, burri më i mirë në një fshat, në një rreth familjar etj.; dash me këmborë. Shpendi ka qenë dash me flokë në të tanë krahinën e jo vetëm në katundin tonë. (Ligj. fol.).

Dash me këmborë. 1. Njeri i zoti e i shquar, i pari ndër të tjerët; dash me flokë. - $E$ ka atë djalin e vogël, dash me këmborë, ai ka për ta nxjerrë në selamet Zenon. (Ligj. fol.). 2. Kryetari i familjes a i fisit. - Ti je dashi me këmborë në fis, ç'të na thuash ti do të bëjmë. (Ligj. fol.). 3. Udhëheqës, prijës.- Printe para me shpatë në dorë, / Ballë trimash dash me këmborë. (Folk.).

Derr në kotec (në thark) shumë i mërzitur (ngaqë nuk kam dalë a nuk kam lëvizur).

- Kam gjashtë muaj pa dalë, mbeta brenda e u bëra derr në thark. (Let. art.).

Derr me zile shar. njeri shumë i trashë nga mendja dhe i neveritshëm.

- More, derr me zile, ç'më vure kështu në kokë? - Mbaje me shëndet! - $i$ tha Kadriu dhe i shkeli syrin. (Let. art.). 
vjetër.

Dhelpër plakë (e vjetër) njeri shumë dinak, i regjur në hile e dredhi; skile e

-Ai, i dashur, ka qenë dhelpër plakë... E vlerësoi gjendjen dhe e ktheu drejtimin e barkës nga perëndimi. (Let. art.).

Dhi arrakate shar. vajzë që nuk mblidhet në shtëpi, që bredh poshteë e përpjetë; vajzë e egër, e pashtruar në pune a në shkollë; dhi e egër.

Lushja dhi arrakate ka qenë që e vogël, dy gurë bashkë nuk linte, dhe ashtu mbeti. (Let. art).

$\sim$ Dhi e egër vajze a grua e gjallë a e shkathët, por jo e afrueshme; dhi arrakate shar.

\section{Conclusions}

One of the main features of phraseology is the figurative meanings that the words get when combined in a phraseological unit. The English language is considered as an idiomatic one. Thus, making it more difficult to be learned by the foreigners, due to these semantic shifts that the words acquire when they become part of a phraseological unit. In this paper it has been observed that the majority of the phraseological units are formed by the use of linguistic tropes where metaphor and simile occupy the main part. Nevertheless there are phraseological units which are formed by the use of other linguistic tropes like metonymy, synecdoche etc. In both languages it has been noticed that the words get other meanings apart from the literal one, which as a result enrich the vocabulary with new phraseological units. Phraseological units are important for the students of a foreign language, as it shows a nativelike level of the language proficiency. Hence phraseological units must be part of the everyday learning in order to be acquired effectively and accurately. Both teachers and students must be aware of the importance that phraseological units have and must make it a priority in the teaching and learning activities.

\section{References}

[1] Danesi, M. (1992), Metaphorica competence in second language acquisition and second language teaching, Washington, DC , Georgetown University press

[2] Fromilhague, C. (1995), Les figures de style, Paris: Nathan

[3] Glucksberg, S. (1996), Understanding Figurative Language : From Metaphor to Idioms: From Metaphor ...

[4] Knowles, M. \& Moon, R. (2006), Introducing Metaphor

[5] Lakoff, G. \& Johnson, M (1980), Metaphors we live by, Chicago, Chicago University Press

[6] Lazar, G. (1996), Using figurative language to expand student's vocabulary. ELT Journal

[7] Littlemore, J. (2003) "The effect of cultural background on metataphor interpretation" Metaphor and Symbol

[8] Littlemore, J. (2003), The effect of cultural background on metataphor interpretation" Metaphor and Symbol" f. 278

[9] Mac Cormac, R. (1985), Cognitive Theory of Metaphor

[10] Memisha, V. (1999), Studime për fjalën shqipe, Tiranë

[11] Moon, Rosamund. 1998. Fixed Expressions and Idioms in English. A Corpus-based Approach.

[12] Ortony, A. (1993), The Role of Similarity in Similes and Metaphors. In Andrew Ortony (ed.). Metaphor and Thought. Cambridge: Cambridge University Press, 2nd edn. [1st edn.

[13] Oxford: Oxford University Press.

[14] Punter, D. (2007). Metaphor, London, Routledge

[15] Stefanllari, I. (1998), Fjalori Frazeologjik Anglisht - Shqip

[16] Stefanllari, I. (1998), Fjalori Frazeologjik Anglisht - Shqip, Tiranë 
[17] Thomai, J. (1999), Fjalor Frazeologjik i Gjuhës Shipe

[18] V. Memisha, Rreth intelektualizimit të leksikut të shqipes, në Seminari II Ndërkombëtar i Albanologjisë, Tetovë, 2008, f. 196 